\title{
Comparative analysis of the emotional state of persons involved in terrorist activities
}

\author{
Kyuri Idrisov ${ }^{1,2 *}$, Islam Khazhuev ${ }^{2}$, and Aslanbek Saidov ${ }^{2}$ \\ ${ }^{1}$ Chechen State University, 364068, Grozny, Russian Federation \\ ${ }^{2}$ Chechen State Pedagogical University, Grozny 364068, Russian Federation
}

\begin{abstract}
The paper presents the results of a study of mental states in persons prosecuted for terrorist activities, as well as a comparative analysis of their indicators with a control group selected from among ordinary youth of the Chechen Republic. The purpose of the study is to identify the characteristics of mental states, as well as the leading signs of anxiety, aggressiveness, frustration and rigidity, taking into account the presence or absence of an individual's criminal past associated with terrorist activities. As part of the experiment, 67 people were interviewed, 32 of whom were in the past active participants in terrorist organizations banned on the territory of Russia and at the time of the study are under investigation or are already serving a sentence for committed crimes.
\end{abstract}

\section{Introduction}

Throughout the history of its existence, humanity has faced various forms and manifestations of terrorism. This phenomenon reached a special scope in the late XX - early XXI century. Terrorist acts and sabotage, cruel in their manifestation, receive a wide resonance throughout the world, causing not only just public outrage, but also serious fears for peace and security on the planet [1].

Breaking the socio-economic difficulties, religious, national and ethnic contradictions of any society into a political plane, the ideologues of extremism and terrorism use them as a tool and means to incite conflicts [2], creating a real threat to the national security of any state [3].

Along with many states of the world, modern Russia, for which the threat of terrorism is still relevant today, has faced directly manifestations of terrorism. At the same time, modern terrorism is a complex system consisting of a complex of complementary processes - ideological, criminal, military, economic, political, religious and nationalistic [4].

As V.S. Kryazhev [5] and M.A. Vershkova [6] in modern conditions there is an escalation of terrorist activities of extremist-minded individuals, groups and organizations, its nature is becoming more complex, the sophistication and antihumanity of terrorist acts are increasing.

Unlike other criminal acts, terrorism is carried out with the aim of realizing some ideas. In this regard, it should be considered that the moral and psychological traits of a terrorist are based on the ideology of terrorism, which are reflected in his specificity, emotional and

\footnotetext{
* Corresponding author: kyuri.idrisov@yandex.ru
} 
mental state, ways of perception and attitude to the external world, on the interaction of his internal and external world [7].

One of the most important and difficult tasks in the study of the problem of terrorism in modern society is the study of the personality of a terrorist. A modern terrorist is, as a rule, an aggressive, alienated, repeatedly prosecuted and served a sentence, a representative of the underworld, with serious criminal experience, with a rather low level of education and almost complete absence of any spiritual and ideological impulses [8]. At the same time, it is impossible to single out a universal type of terrorist, but one can only conditionally single out some signs that characterize a terrorist, the most likely of which are representatives of the criminal environment and people with mental disorders [9].

Thus, according to some Russian authors [10], terrorists have the following main characteristics: 1) a tendency to constantly search for various sources of personal problems; 2) continuous being in a state of tension and, in connection with this, readiness to go on the defensive at any time; 3) vision of a threat where it is not; 4) preservation of feelings and emotions that a person experienced for one reason or another, and these reasons have long disappeared. 5) intolerance; 6) the behavior of the terrorist is in most cases polymotivated; 8) an increase in suicide cases among persons under the age of thirty [11].

At the same time, despite the fact that the phenomenon of terrorism depends on a set of circumstances affecting wide layers of society, in fact, only a small part of it lends itself to radicalization, taking the criminal path of terrorism and extremism. According to a number of authors, psychological features that cause possible antisocial behavior in the mainstream of a terrorist orientation include such psychological traits as anxiety, frustration, aggressiveness, narcissism and rigidity $[7,12,13]$.

At the same time, the experience of individual mental states, in the form of anxiety, frustration, rigidity, makes significant adjustments to the perception of personality [14] and can contribute to the exacerbation of more serious structural personality anomalies, complexes of superiority over others [15], serious problems with critical analysis of reality and his own person against the background of denial of the right to choose and alternative $[6,16]$.

According to a number of authors, one of the personality traits, which is in many ways a source for the development of extreme violent inclinations of the individual, is an acute sense of dissatisfaction with the natural needs of the individual, manifested as frustration [17], in which the internal attitudes of the personality, its ideological orientation become primarily rigid: if surrounding people do not share such a vision, then they are subjected to contempt, persecution and hatred [18].

According to Yu.M. Antonyan and E.N. Yurasov, anxiety of the individual, expressed in low resistance to uncertainty, is of great importance among the psychological characteristics of persons prone to manifestation of extremism, and, accordingly, terrorism in its extreme forms of development $[19,20]$. S. E. Voronin adheres to the same point of view, highlighting such distinctive features of religious extremists as uncertainty, concern and anxiety in the study of crimes related to religious extremism [21].

At the same time, another characteristic feature of persons prone to extremist and terrorist activities is apparently rigidity (from the Latin "rigidus" or "rigiditas" - hard, hard, frozen), manifested in the form of discomfort when a personality collides with a new and changing one with a predominance of need in organizing life according to the usual order. At the same time, a limited, focused interest in the external world, its perception through the prism of prejudices, becomes the consequences of a rigid purposefulness. As D. Shapiro notes, with rigidity, features of masochism prevail - a careful, accentuated and attentive attitude to all injustice towards oneself, humiliation, insults, concessions and surrenders, the demand for sympathy and increased attention. However, in this case, the person does not 
remain in the humility of the martyr, on the contrary, irritation, anger, bitterness, a sense of injustice are manifested $[22,23]$.

Objectives of the study. The study of the characteristics of the emotional state of persons involved in terrorist activities in order to establish emotional patterns involved in the formation of a terrorist deformation in the personality.

\section{Materials and methods}

The study involved two groups of young people. The first group - experimental, included 32 people. Under investigation for participation in terrorist crimes (average age $27 \pm 5$ ) and the second group - the control group. included 35 people - representatives of student youth, selected at random (average age $22 \pm 3$ ).

Research methods. Eysenck's mental health questionnaire; clinical and demographic map for collecting personal data.

Statistical data processing methods. Frequency analysis, Student's t-test, Friedman's test.

\section{Research results}

So, the analysis of the frequency of prevalence of levels of severity of mental states among individuals from the control and experimental groups showed how pronounced certain mental states are.

Table 1. Severity levels of anxiety and aggressiveness states in the experimental and control groups

\begin{tabular}{|c|c|c|c|c|c|c|}
\hline Sample & $\begin{array}{c}\text { Anxiety } \\
\text { levels }\end{array}$ & $\mathrm{N}$ & $\%$ & $\begin{array}{c}\text { Aggressiveness } \\
\text { levels }\end{array}$ & $\mathrm{N}$ & $\%$ \\
\hline \multirow{4}{*}{$\begin{array}{c}\text { Experimental } \\
\text { group }\end{array}$} & Low level & 21 & 65.6 & Low level & 27 & 84.4 \\
\cline { 2 - 7 } & $\begin{array}{c}\text { Average } \\
\text { level }\end{array}$ & 7 & 21.9 & Average level & 5 & 15.6 \\
\cline { 2 - 7 } & High level & 4 & 12.5 & High level & 0 & 0.0 \\
\cline { 2 - 8 } & Total & 32 & 100.0 & Total & 32 & 100.0 \\
\hline \multirow{4}{*}{ Control group } & Low level & 23 & 65.7 & Low level & 19 & 54.3 \\
\cline { 2 - 8 } & $\begin{array}{c}\text { Average } \\
\text { level }\end{array}$ & 8 & 22.9 & Average level & 16 & 45.7 \\
\cline { 2 - 8 } & High level & 4 & 11.4 & High level & 0 & 0.0 \\
\cline { 2 - 8 } & Total & 35 & 100.0 & Total & 35 & 100.0 \\
\hline
\end{tabular}

Thus, it was found that $65.6 \%$ of persons from the experimental group have a low level of anxiety versus $65.7 \%$ of the control group. Average and high rates were noted in $21.9 \%$ and $12.5 \%$ of persons with a terrorist past (in the control group, an average and high level of anxiety was noted in $22.9 \%$ and $11.4 \%$ of respondents, respectively). At the same time, according to the level of severity of aggressiveness in the experimental group, $84.4 \%$ have a low level, and $15.6 \%$ - an average one. In the control group, $54.3 \%$ of respondents have a low level of aggressiveness, and an average level was noted in $45.7 \%$ of respondents, respectively. A high level of aggressiveness was not found in any person in both the experimental and control groups. 
Table 1.1. The severity levels of the states of rigidity and frustration in the experimental and control groups

\begin{tabular}{|c|c|c|c|c|c|c|}
\hline Sample & $\begin{array}{c}\text { Anxiety } \\
\text { levels }\end{array}$ & $\mathrm{N}$ & $\%$ & $\begin{array}{c}\text { Aggressiveness } \\
\text { levels }\end{array}$ & $\mathrm{N}$ & $\%$ \\
\hline \multirow{4}{*}{$\begin{array}{c}\text { Experimental } \\
\text { group }\end{array}$} & Low level & 23 & 71.9 & Low level & 21 & 65.6 \\
\cline { 2 - 7 } & $\begin{array}{c}\text { Average } \\
\text { level }\end{array}$ & 5 & 15.6 & Average level & 10 & 31.3 \\
\cline { 2 - 7 } & High level & 4 & 12.5 & High level & 1 & 3.1 \\
\cline { 2 - 7 } & Total & 32 & 100.0 & Total & 32 & 100.0 \\
\hline \multirow{4}{*}{ Control group } & Low level & 8 & 22.9 & Low level & 26 & 74.3 \\
\cline { 2 - 7 } & $\begin{array}{c}\text { Average } \\
\text { level }\end{array}$ & 24 & 68.9 & Average level & 7 & 20.0 \\
\cline { 2 - 7 } & High level & 3 & 8.6 & High level & 2 & 5.7 \\
\cline { 2 - 7 } & Total & 35 & 100.0 & Total & 35 & 100.0 \\
\hline
\end{tabular}

At the same time, the levels of severity of rigidity in the experimental group are as follows: low level in $71.9 \%$ (versus $22.9 \%$ in the control group), average in $15.6 \%(68.6 \%$ in the control group) and high in $12.5 \%$ ( $8.6 \%$ of individuals in the control group). At the same time, $65.6 \%$ of persons from the experimental group have a low level of frustration (in the control group, $74.3 \%$ have a low level), $31.3 \%$ and $3.1 \%$ have medium and high levels (versus $20 \%$ and 5, 7\% in the control group), respectively.

Table 2. Comparative analysis of the severity of mental states in individuals from the experimental and control groups

\begin{tabular}{|c|c|c|c|c|}
\hline Mental states & Sample & $\mathrm{N}$ & Average & \multirow{2}{*}{ P-value } \\
\hline \multirow{2}{*}{ Anxiety } & Experimental group & 32 & 6.56 & \multirow{2}{*}{0.516} \\
\cline { 2 - 4 } & Control group & 35 & 7.37 & \\
\hline \multirow{2}{*}{ Frustration } & Experimental group & 32 & 5.06 & \multirow{2}{*}{0.488} \\
\cline { 2 - 4 } & Control group & 35 & 5.86 & \multirow{2}{*}{0.000} \\
\hline \multirow{2}{*}{ Riggressiveness } & Experimental group & 32 & 3.50 & \multirow{2}{*}{0.000} \\
\cline { 2 - 4 } & Control group & 35 & 7.69 & \\
\cline { 2 - 4 } & Experimental group & 32 & 5.91 & \multirow{2}{*}{0.29} \\
\cline { 2 - 4 } & Control group & 35 & 10.29 & \\
\hline
\end{tabular}

As the results of a comparative analysis of averages show, it has been reliably established that the level of aggressiveness and rigidity is more pronounced in individuals from the control group. This indicates that persons with a terrorist past at the time of the survey showed lower values for aggressiveness and intransigence (rigidity) compared to persons without problems with the law.

As part of the study of the social and environmental specifics of experiencing mental states, the parameters of anxiety, aggressiveness, frustration and rigidity were analyzed depending on the place of residence (city / village). The results of the comparative analysis revealed significant differences in urban and rural residents in the experimental group (Table 3).

Table 3. Comparative analysis of the severity of mental states in individuals from the experimental and control groups

\begin{tabular}{|c|c|c|c|c|c|}
\hline Sample & Mental states & Town/village & N. & Average & P-value \\
\hline \multirow{2}{*}{ Experimental group } & Anxiety & Town & 24 & 4.75 & 0.001 \\
\cline { 3 - 5 } & & Village & 8 & 12.00 & \\
\cline { 2 - 5 } & Frustration & Town & 24 & 3.42 & 0.000 \\
\hline
\end{tabular}




\begin{tabular}{|c|c|c|c|c|c|}
\hline & & Village & 8 & 10.00 & \\
\hline & \multirow[t]{2}{*}{ Aggressiveness } & Town & 24 & 2.08 & \multirow[t]{2}{*}{0.000} \\
\hline & & Village & 8 & 7.75 & \\
\hline & \multirow[t]{2}{*}{ Rigidity } & Town & 24 & 4.75 & \multirow[t]{2}{*}{0.018} \\
\hline & & Village & 8 & 9.38 & \\
\hline \multirow[t]{8}{*}{ Control group } & \multirow[t]{2}{*}{ Anxiety } & Town & 24 & 7.62 & \multirow[t]{2}{*}{0.480} \\
\hline & & Village & 8 & 6.17 & \\
\hline & \multirow[t]{2}{*}{ Frustration } & Town & 24 & 6.24 & \multirow[t]{2}{*}{0.295} \\
\hline & & Village & 8 & 4,00 & \\
\hline & \multirow[t]{2}{*}{ Aggressiveness } & Town & 24 & 7.66 & \multirow[t]{2}{*}{0.913} \\
\hline & & Village & 8 & 7.83 & \\
\hline & \multirow[t]{2}{*}{ Rigidity } & Town & 24 & 10.28 & \multirow[t]{2}{*}{0.973} \\
\hline & & Village & 8 & 10.33 & \\
\hline
\end{tabular}

A comparative analysis of the parameters of mental states, carried out depending on the actual place of residence of persons who committed terrorist crimes (experimental group), revealed that representatives of the village are most susceptible to the development of high anxiety, aggressiveness, frustration and rigidity in comparison with residents of cities who have committed similar crimes. At the same time, persons from the control group, also divided into representatives of the city and the village, showed excellent results. Thus, in the control group, the representatives of the city are more dominated by mental states of anxiety and frustration, while residents of rural areas are more susceptible to high aggressiveness and rigidity, but these differences are not statistically significant $(\mathrm{p} \geq 0.05)$.

At the same time, a comparative analysis of the severity of mental states in general for the samples showed that individuals from the experimental group are prone to anxiety, while rigidity dominates in the control sample (Table 4).

Table 4. Distribution according to the mean values of the parameters of mental states in the experimental and control groups

\begin{tabular}{|c|c|c|c|c|c|}
\hline Sample & Mental states & $\mathrm{N}$ & Average & Rank & P-value \\
\hline Experimental group & Anxiety & 32 & 6.56 & 1 & \multirow{3}{*}{0.000} \\
\cline { 2 - 5 } & Frustration & 32 & 5.06 & 3 & \\
\cline { 2 - 5 } & Aggressiveness & 32 & 3.50 & 4 & \\
\cline { 2 - 5 } & Rigidity & 32 & 5.91 & 2 & \\
\hline \multirow{3}{*}{ Control group } & Anxiety & 35 & 7.37 & 3 & \multirow{3}{*}{0.000} \\
\cline { 2 - 5 } & Frustration & 35 & 5.86 & 4 & \\
\cline { 2 - 5 } & Aggressiveness & 35 & 7.69 & 2 & \\
\cline { 2 - 5 } & Rigidity & 35 & 10.29 & 4 & \\
\hline
\end{tabular}

In the experimental group, the state of anxiety (rank 1) predominates, in comparison with which rigidity (rank 2) and frustration (rank 3) are less pronounced, and aggressiveness (rank 4) in persons with a terrorist past has the lowest indicators in comparison with the indicated mental states $(p=0.000)$. At the same time, the control group is dominated by rigidity (rank 1) and less pronounced, respectively, the states of aggressiveness (2), anxiety (3) and frustration (4) $(\mathrm{p}=0.000)$.

In addition, within the framework of the study, individual signs of the considered mental states were analyzed using Eysenck's method, which made it possible to identify the most pronounced signs in the context of anxiety, rigidity, aggressiveness and frustration. 
Table 5. Distribution of signs of anxiety in order of their severity

\begin{tabular}{|c|c|c|c|c|}
\hline Sample & Signs of anxiety & $\begin{array}{c}\text { Middle } \\
\text { rank }\end{array}$ & Rank & $\begin{array}{l}\text { Chi-square } \\
\text { and p-value }\end{array}$ \\
\hline \multirow{10}{*}{$\begin{array}{l}\text { Experimental } \\
\text { group } \\
(\mathrm{n}=32)\end{array}$} & I don't feel confident in myself. & 4.04 & 10 & \multirow{10}{*}{$\begin{aligned} \chi^{2} & =37.481 \\
p & =0.000\end{aligned}$} \\
\hline & Often I blush because of trifles. & 4.52 & 9 & \\
\hline & My sleep is restless. & 5.78 & 4 & \\
\hline & I get discourage deasily. & 5.44 & 6 & \\
\hline & $\begin{array}{l}\text { I only worry about the imaginary } \\
\text { troubles. }\end{array}$ & 4.89 & 8 & \\
\hline & Difficulties scare me. & 4.93 & 7 & \\
\hline & $\begin{array}{l}\text { I love to delve into my } \\
\text { shortcomings. }\end{array}$ & 6.28 & 3 & \\
\hline & It's easy to convince me. & 6.61 & 2 & \\
\hline & I'm suspicious. & 5.63 & 5 & \\
\hline & I can hardly stand the waiting time. & 6.89 & 1 & \\
\hline \multirow{10}{*}{$\begin{array}{l}\text { Control } \\
\text { group } \\
(\mathrm{n}=35)\end{array}$} & I don't feel confident in myself. & 6.37 & 3 & \multirow{10}{*}{$\begin{aligned} \chi^{2} & =44.211 \\
p & =0.000\end{aligned}$} \\
\hline & Often I blush because of trifles. & 5.29 & 5 & \\
\hline & My sleep is restless. & 4.34 & 10 & \\
\hline & I get discourage deasily. & 4.66 & 9 & \\
\hline & $\begin{array}{l}\text { I only worry about the imaginary } \\
\text { troubles. }\end{array}$ & 5.04 & 7 & \\
\hline & Difficulties scare me. & 4.76 & 8 & \\
\hline & $\begin{array}{l}\text { I love to delve into my } \\
\text { shortcomings. }\end{array}$ & 6.79 & 2 & \\
\hline & It's easy to convince me. & 5.66 & 4 & \\
\hline & I'm suspicious. & 5.06 & 6 & \\
\hline & I can hardly stand the waiting time. & 7.04 & 1 & \\
\hline
\end{tabular}

Table 5.1. Distribution of signs of frustration in order of their severity

\begin{tabular}{|c|c|c|c|c|}
\hline Sample & Signs of anxiety & $\begin{array}{l}\text { Middle } \\
\text { rank }\end{array}$ & Rank & $\begin{array}{l}\text { Chi-square } \\
\text { and p-value }\end{array}$ \\
\hline \multirow[t]{9}{*}{$\begin{array}{l}\text { Experimental } \\
\text { group } \\
(\mathrm{n}=32)\end{array}$} & $\begin{array}{l}\text { Often I seem to be a hopeless } \\
\text { situation from which to e you can } \\
\text { still find a way out. }\end{array}$ & 6.23 & 1 & \multirow[t]{9}{*}{$\begin{array}{c}\chi^{2}=19.348 \\
p=0.022\end{array}$} \\
\hline & $\begin{array}{c}\text { Trouble makes me very upset, I lose } \\
\text { heart. }\end{array}$ & 5.14 & 9 & \\
\hline & $\begin{array}{l}\text { When I'm in big trouble, I tend to } \\
\text { blame myself unnecessarily. }\end{array}$ & 5.27 & 8 & \\
\hline & $\begin{array}{l}\text { Misfortune and failure teach me } \\
\text { nothing. }\end{array}$ & 6.14 & 3 & \\
\hline & $\begin{array}{l}\text { I often refuse to fight, considering it } \\
\text { fruitless. }\end{array}$ & 6.16 & 2 & \\
\hline & I often feel defenseless. & 5.32 & 7 & \\
\hline & Sometimes I feel desperate. & 5.80 & 4 & \\
\hline & $\begin{array}{l}\text { I feel confused in front of } \\
\text { difficulties. }\end{array}$ & 5.46 & 5 & \\
\hline & $\begin{array}{l}\text { In difficult moments of life, } \\
\text { sometimes I behave like a child, I } \\
\text { want to be sorry. }\end{array}$ & 5.30 & 6 & \\
\hline
\end{tabular}




\begin{tabular}{|c|c|c|c|c|}
\hline & $\begin{array}{l}\text { I consider my flaws in my character } \\
\text { incorrigible. }\end{array}$ & 4.16 & 10 & \\
\hline \multirow[t]{10}{*}{$\begin{array}{l}\text { Control group } \\
(n=35)\end{array}$} & $\begin{array}{l}\text { Often I seem to be a hopeless } \\
\text { situation from which to e you can } \\
\text { still find a way out. }\end{array}$ & 5.59 & 6 & \multirow[t]{10}{*}{$\begin{aligned} \chi^{2} & =31.564 \\
p & =0.000\end{aligned}$} \\
\hline & $\begin{array}{l}\text { Trouble makes me very upset, I lose } \\
\text { heart. }\end{array}$ & 5.70 & 5 & \\
\hline & $\begin{array}{l}\text { When I'm in big trouble, I tend to } \\
\text { blame myself unnecessarily. }\end{array}$ & 5.73 & 4 & \\
\hline & $\begin{array}{l}\text { Misfortune and failure teach me } \\
\text { nothing. }\end{array}$ & 5.83 & 3 & \\
\hline & $\begin{array}{l}\text { I often refuse to fight, considering it } \\
\text { fruitless. }\end{array}$ & 6.30 & 2 & \\
\hline & I often feel defenseless. & 4,00 & 10 & \\
\hline & Sometimes I feel desperate. & 6.49 & 1 & \\
\hline & $\begin{array}{l}\text { I feel confused in front of } \\
\text { difficulties. }\end{array}$ & 5.19 & 8 & \\
\hline & $\begin{array}{l}\text { In difficult moments of life, } \\
\text { sometimes I behave like a child, I } \\
\text { want to be sorry. }\end{array}$ & 4.96 & 9 & \\
\hline & $\begin{array}{l}\text { I consider my flaws in my character } \\
\text { incorrigible. }\end{array}$ & 5.23 & 7 & \\
\hline
\end{tabular}

Table 5.2. Distribution of signs of aggressiveness in order of their severity

\begin{tabular}{|c|c|c|c|c|}
\hline Samples & Signs of aggressiveness & $\begin{array}{l}\text { Middle } \\
\text { rank }\end{array}$ & Rank & $\begin{array}{l}\text { Chi-square } \\
\text { and p-value }\end{array}$ \\
\hline \multirow{10}{*}{$\begin{array}{l}\text { Experimental } \\
\text { group } \\
(n=32)\end{array}$} & $\begin{array}{l}\text { I reserve the last word for } \\
\text { myself. }\end{array}$ & 4.54 & 8 & \multirow[t]{10}{*}{$\begin{aligned} \chi^{2} & =26.150 \\
p & =0,002\end{aligned}$} \\
\hline & $\begin{array}{c}\text { I often interrupt my interlocutor in a } \\
\text { conversation. }\end{array}$ & 5.89 & 4 & \\
\hline & It's easy to piss me off. & 6.54 & 1 & \\
\hline & I love making comments to others. & 5.57 & 5 & \\
\hline & I want to be an authority for others. & 5.36 & 7 & \\
\hline & $\begin{array}{l}\text { I am not content with little, I want } \\
\text { the most. }\end{array}$ & 5.36 & 7 & \\
\hline & $\begin{array}{l}\text { When I get angry, I hold back } \\
\text { myself badly. }\end{array}$ & 5.93 & 3 & \\
\hline & I prefer to lead rather than obey. & 5.98 & 2 & \\
\hline & I have harsh, rude gestures. & 4.38 & 9 & \\
\hline & I'm vengeful. & 5.46 & 6 & \\
\hline \multirow{7}{*}{$\begin{array}{l}\text { Control } \\
\text { group } \\
(n=35)\end{array}$} & $\begin{array}{l}\text { I reserve the last word for } \\
\text { myself. }\end{array}$ & 5.77 & 4 & \multirow[t]{7}{*}{$\begin{aligned} \chi^{2} & =23.312 \\
p & =0.006\end{aligned}$} \\
\hline & $\begin{array}{c}\text { I often interrupt my interlocutor in a } \\
\text { conversation. }\end{array}$ & 5.66 & 5 & \\
\hline & It's easy to piss me off. & 5.11 & 8 & \\
\hline & I love making comments to others. & 5.17 & 7 & \\
\hline & I want to be an authority for others. & 5.57 & 6 & \\
\hline & $\begin{array}{l}\text { I am not content with little, I want } \\
\text { the most. }\end{array}$ & 5.83 & 3 & \\
\hline & When I get angry, I hold back & 6.53 & 1 & \\
\hline
\end{tabular}




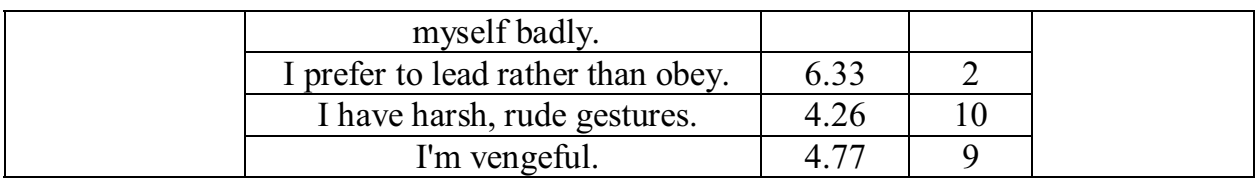

Table 5.3. Distribution of signs of rigidity in order of their severity

\begin{tabular}{|c|c|c|c|c|}
\hline Samples & Signs of rigidity & $\begin{array}{l}\text { Middle } \\
\text { rank }\end{array}$ & Rank & $\begin{array}{l}\text { Chi-square } \\
\text { and p-value }\end{array}$ \\
\hline \multirow{10}{*}{$\begin{array}{l}\text { Experimental } \\
\text { group } \\
(\mathrm{n}=32)\end{array}$} & $\begin{array}{l}\text { I find it difficult to change } \\
\text { habits. }\end{array}$ & 5.66 & 5 & \multirow[t]{10}{*}{$\begin{array}{c}\chi^{2}=15.14 \\
p=0.087\end{array}$} \\
\hline & It's not easy to shift attention. & 5.16 & 7 & \\
\hline & I am very wary of everything new. & 5.98 & 3 & \\
\hline & It's hard to convince me. & 5.09 & 8 & \\
\hline & $\begin{array}{l}\text { Often a thought does not go out of } \\
\text { my head, from which I should free } \\
\text { myself. }\end{array}$ & 6.05 & 2 & \\
\hline & $\begin{array}{c}\text { I have a hard time getting close to } \\
\text { people. }\end{array}$ & 4.63 & 10 & \\
\hline & \begin{tabular}{|c|} 
Even minor violations of the plan \\
upset me.
\end{tabular} & 5.59 & 6 & \\
\hline & I am often stubborn. & 4.70 & 9 & \\
\hline & I am reluctant to take risks. & 6.38 & 1 & \\
\hline & $\begin{array}{c}\text { I am very worried about } \\
\text { deviations from the daily routine } \\
\text { that I have adopted. }\end{array}$ & 5.77 & 4 & \\
\hline \multirow[t]{10}{*}{$\begin{array}{l}\text { Control group } \\
(\mathrm{n}=35)\end{array}$} & $\begin{array}{l}\text { I find it difficult to change } \\
\text { habits. }\end{array}$ & 6.30 & 3 & \multirow[t]{10}{*}{$\begin{array}{l}\chi^{2}=26.74 \\
p=0.002\end{array}$} \\
\hline & It's not easy to shift attention. & 5.06 & 7 & \\
\hline & I am very wary of everything new. & 5.03 & 8 & \\
\hline & It's hard to convince me. & 5.26 & 6 & \\
\hline & $\begin{array}{l}\text { Often a thought does not go out of } \\
\text { my head, from which I should free } \\
\text { myself. }\end{array}$ & 6.31 & 2 & \\
\hline & $\begin{array}{c}\text { I have a hard time getting close to } \\
\text { people. }\end{array}$ & 4.91 & 9 & \\
\hline & \begin{tabular}{|c|}
$\begin{array}{c}\text { Even minor violations of the plan } \\
\text { upset me. }\end{array}$ \\
\end{tabular} & 5.50 & 5 & \\
\hline & I am often stubborn. & 6.66 & 1 & \\
\hline & I am reluctant to take risks. & 5.66 & 4 & \\
\hline & $\begin{array}{c}\text { I am very worried about } \\
\text { deviations from the daily routine } \\
\text { that I have adopted. }\end{array}$ & 4.31 & 10 & \\
\hline
\end{tabular}

So, according to the results of ranking the answers according to Eysenck's method, in the experimental group the most pronounced mental state on the scale "Anxiety" is a feeling of difficulty associated with the waiting time ("I can hardly stand the waiting time"), as well as the inability to counteract suggestive influences ("Me easy to convince"), while the least common feeling of self-doubt ("I don't feel confident in myself") $(\chi 2=37.481 ; p$ $=0.000)$. In the control group, the most popular is also the state associated with waiting time ("I can hardly stand the waiting time") and the least represented experience associated with restless sleep ("My sleep is restless") $(\chi 2=44.211 ; \mathrm{p}=0.000)$. 
Within the scale of "Frustration", the most pronounced in the experimental group is the state associated with a feeling of a hopelessness of a situation, from which it is still possible to find a way out ("Often it seems to me hopeless situations from which it is still possible to find a way out") and less widespread is the opinion about incorrigibility of shortcomings of my own character ("I consider my shortcomings to be incorrigible") $(\chi 2=19.348 ; \mathrm{p}=$ 0.022). In the control group, a more popular frustration state associated with a state of despair ("Sometimes I have a state of despair") and less common a feeling of their own defenselessness ("I often feel defenseless") $(\chi 2=31.564 ; \mathrm{p}=0.000)$.

Among the signs of aggressiveness in the experimental group, the answer "I can easily get angry" prevails, while the least common variant is the presence of sharp and rude gestures $(\chi 2=26.150 ; p=0.002)$. At the same time, in the control group, the most popular option is "When I get angry, I hold back myself badly" and the least common, as in the experimental group, is the option "I have a sharp, rude gesture" $(\chi 2=23.312 ; p=0.006)$.

In the complex of signs of rigidity in the experimental group, the prevailing lack of desire to take risks ("I'm reluctant to take risks") and, on the contrary, the lowest indicators in the option "I do not get close to people" $(\chi 2=15.147 ; \mathrm{p}=0.087)$. In the control sample, the manifestation of stubbornness is more popular ("I often show stubbornness") and the least pronounced deviation from the accepted daily routine ("I feel strongly about deviations from the daily routine I have adopted") $(\chi 2=26.746 ; \mathrm{p}=0.002)$.

\section{Discussion}

In the present study, the parameters of the development of mental states were analyzed in the context of an individual's involvement in terrorist activities. As the results of the study show, persons who committed crimes of a terrorist nature turned out to be less susceptible to reactions of aggression and rigidity in comparison with young people who have no criminal past. The explanation of these differences is possible through the action of two main simultaneously acting factors - social and psychological.

As social predictors and conditions for exacerbation of mental states in individuals from the control group, which consisted of young people, the period of strict self-isolation in the Chechen Republic in connection with the coronavirus pandemic, when, as a result of a long-term self-isolation regime in the mental space of an individual (a young person and ordinary life characterized by impulsivity), tension, a feeling of discontent and aggressiveness could accumulate, and the inability to communicate and interact with other people could significantly narrow the mechanisms of sublimation of these negative experiences. On the contrary, persons detained by law enforcement agencies for terrorist crimes have already shown their negative intrapersonal experiences in specific types of activity (in this case, terrorist) and, as a result, ended up in the hands of justice, this in turn could also stimulate the development of more socially justified and correct forms of behavior, including also trying to demonstrate a less aggressive and rigid nature. At the same time, among those involved in terrorist crimes, people from rural areas are more susceptible to the development of anxiety, aggressiveness, frustration and rigidity, which may be explained by the socio-economic characteristics of living in rural areas. Nevertheless, among young people without a criminal past, no differences were found in the severity of mental states depending on their actual place of residence, in contrast to those with a terrorist orientation.

In the context of the terrorist orientation of the personality, difficulties with the waiting time can be caused by stationary anxiety and fear associated with a vital threat and the expectation of the inevitability of punishment for what they have done, while in young people who are not involved in terrorist activities, this state can be determined as individual psychological characteristics, and the social and environmental factor (the regime of long- 
term self-isolation). At the same time, being involved in the activities of terrorist organizations, persons detained by law enforcement agencies could for a long time feel a state of frustration, not finding ways to return to a peaceful life. At the same time, this condition could also have worsened as a result of the arrest and the commenced judicialproduction process within the framework of a criminal case. Having, on the one hand, a tendency to irascibility, persons with a terrorist orientation also demonstrate the ability to exercise caution without unnecessarily risking, which is explained by the strict observance of the conspiracy rules of the terrorist organization itself, according to I.V. Belasheva et al. Is one of the features of an individual's membership in a terrorist group on a par with loyalty to this group [1].

Research in the direction of studying the mental states of persons involved in terrorist activities is of high scientific interest. The results of this study make it possible to understand the peculiarities of the course of mental states of a person involved in the commission of especially grave crimes, and to consider the peculiarities of his mental status and behavior after the crime and the subsequent detention by law enforcement agencies.

\section{Conclusion}

1. It has been established that aggressiveness and rigidity as mental states are more pronounced in young people who are not involved in terrorist crimes in comparison with persons detained by law enforcement agencies for involvement in terrorist organizations.

2. People from rural areas who are involved in committing crimes of a terrorist nature are more susceptible to the development of anxiety, frustration, aggressiveness and tendencies of rigidity than people from the urban environment.

3. The dominant mental state among persons with a terrorist orientation is anxiety, while young people who are not involved in such crimes are more susceptible to rigidity.

4. Persons arrested for involvement in terrorist activities have more pronounced experiences associated with the waiting time, a sense of the hopelessness of their own situation, irascibility and weakness of desire to take a risky act.

The reported study was funded by Russian Foundation for Basic Research (RFBR), project number 20-013-00239.

\section{References}

1. I.V. Belasheva, D.A. Ershova, M.L. Esayan, Psychology of terrorism: a tutorial (Publishing house of NCFU, Stavropol, 2016).

2. V.Sh. Sabirov, Extremism as a civilizational challenge: collective monograph (NGASU, Novosibirsk, 2012).

3. O.M. Pisarev, E.P. Molchanova, Bulletin of the Tomsk Institute for Advanced Training of Employees of the Federal Penitentiary Service of Russia 1 (3), 91-108 (2020).

4. A.B. Protopopova, Psychological features of terrorist, destructive and extremist groups. Counteracting the ideology of terrorism in the educational sphere and youth: a collection of articles (MGIMO-University, Moscow, 2019).

5. V.S. Kryazhev, Russian investigator 2, 35-39 (2016).

6. M.A. Vershkova, Vestnik MGEI 4, 147-151 (2019).

7. V.M. Kharzinova, Historical and socio-educational thought 4 (1), V8, 112-115 (2016).

8. N.S. Volkova, Symbol of science 7 (2) (2016). 
9. O.G. Pimakova, Victimology 4 (18), 54-58 (2018).

10. L.V. Serdyuk, Violence: Criminological and Criminal Law Research (Yurlitinform, Moscow, 2002).

11. Yu.A. Grachev, I.Yu. Petrov, A.Yu. Sagaidak, Bulletin of St. Petersburg University of the Ministry of Internal Affairs of Russia 3 (71), 101-104 (2016).

12. Yu. A. Ermakov, Bulletin of the Ural Federal University 1 (135), 206-216 (2015).

13. Yu.M. Antonyan, G.I. Belokurov, A.K. Bokovikov, Ethnoreligious terrorism (Aspect Press, Moscow, 2006).

14. M.S. Okshin, Bulletin of the Samara Humanitarian Academy 1 (19), 18-31 (2016).

15. S.S. Oganesyan, L.P. Lobacheva, Criminal executive system: law, economics, management 6, 19-23 (2018).

16. A.S. Kosova, Young scientis 11, 1768-1770 (2016).

17. D.G. Davydov, Sociology of education 10, 4-17 (2013).

18. A.V. Sharapov, Bulletin of the Cherepovets State University 6 (81), 196-204 (2017).

19. Y.M. Antonyan, Lex russica 7, 735-741 (2013).

20. Y.M. Antonyan, Extremism and its causes (Logos, Moscow, 2010).

21. S.E. Voronin, Russian investigator 3, 16-19 (2016).

22. V.A. Osipov, Young scientist 8, 242-246 (2017).

23. D. Shapiro, Autonomy and rigid character (Basic Books, New York, 1981). 